\title{
Ritmos de cambio en la vestimenta y ornamentos de la sociedad Yagán de Tierra del Fuego (siglos XIX y XX)
}

\author{
["Rates of change in clothing and ornaments of the Yagan society of Tierra \\ del Fuego (19th and 20th centuries)"]
}

\author{
Ana Butto \\ (Consejo Nacional de Investigaciones Científicas y Técnicas \\ Centro Austral de Investigaciones Científicas, Argentina) \\ anabutto@gmail.com \\ Danae Fiore \\ (Consejo Nacional de Investigaciones Científicas y Técnicas \\ Asociación de Investigaciones Antropológicas) \\ Universidad de Buenos Aires, Argentina \\ danae_fiore@yahoo.es
}

\begin{abstract}
Resumen
En este trabajo indagaremos en los diferentes ritmos que tuvo la adopción de cultura material occidental por parte de la sociedad Yagán de Tierra de Fuego desde fines del siglo XIX hasta mediados del siglo XX. Para ello, centraremos el análisis en un corpus de 428 fotografías etnográficas de este pueblo originario, obtenidas entre 1881 y 1987 en Tierra del Fuego, a fin de analizar de manera diacrónica la adopción desigual de cultura material occidental, específicamente respecto de la vestimenta y los adornos. De esta manera, esperamos discutir los distintos procesos desarrollados respecto de esta cultura material a partir del contacto con los europeos: adopción plena, adopción parcial (ciclaje), reciclaje y resiliencia. Así, encontramos que los yaganes fueron agentes activos de su propio cambio cultural, que tuvo distintos ritmos vinculados a procesos de negociación y resiliencia, que permitieron la supervivencia física y cultural de este Pueblo Originario.
\end{abstract}

Palabras claves: Fotografía Etnográfica; Cultura Material; Tierra del Fuego; Cambio; Resiliencia.

\begin{abstract}
In this work we will examine the different adoption rhythms of Western material culture by the Yagan society of Tierra de Fuego from the end of the $19^{\text {th }}$ century until the middle of the $20^{\text {th }}$ century. In order to do this, we will focus the analysis on a corpus of 428 ethnographic photographs of this indigenous people, obtained between 1881 and 1987 in Tierra del Fuego, in order to analyze in a diachronic way the unequal adoption of Western material culture, specifically clothing and ornaments. In this way, we hope to discuss the different processes regarding this material culture since the contact with Europeans: full adoption, partial adoption (cycling), recycling, and resilience. Thus, we find that the Yagans were active agents of their own cultural change, which had different rhythms linked to negociation and resilience processes, which allowed the physical and cultural survival of this First Nation.
\end{abstract}

Keywords: Ethnographic Photograph; Material Culture; Tierra del Fuego; Change; Resilience.

Recibido 28/2/20

Evaluado 17/6/20

Aceptado 10/8/20

Anuario de la Escuela de Historia Virtual - Año 11 - N 18 - 2020: pp. 158-187.

ISSN: 1853-7049

http://revistas.unc.edu.ar/index.php/anuariohistoria 


\section{Ritmos de cambio en la vestimenta y ornamentos de la sociedad Yagán de Tierra del Fuego (siglos XIX y XX) ${ }^{1}$}

$\mathrm{E}$

n este trabajo nos proponemos indagar en los diferentes ritmos de cambio que tuvo la cultura material en la sociedad Yagán de Tierra de Fuego desde fines del siglo XIX hasta mediados del siglo XX. Este análisis se orienta a discutir los distintos procesos desarrollados respecto de la cultura material a partir del contacto con los europeos, a fin de recuperar la agencia de estos indígenas fueguinos en ese proceso de interacción intercultural.

Para ello, analizaremos un corpus de 428 fotografías etnográficas de este pueblo originario, obtenidas entre 1881 y 1987 en Tierra del Fuego por 25 fotógrafos. Centraremos el análisis en dos elementos clave de la cultura material registrada en las fotografías: la vestimenta y los adornos, que constituyen un conjunto de prácticas corporales que permiten la comunicación entre diferentes actores sociales (Entwistle, 2000). Consideramos que, dado que la indumentaria implica una serie de modificaciones sobre la materialidad del cuerpo y que, a través de ella, se expresa y comunica la identidad, la vestimenta y el adorno desempeñan un rol activo en los procesos de construcción de identidades (Eicher y Barnes, 1994). Así, entendemos que en las fotografías etnográficas bajo análisis la vestimenta y los adornos corporales con que posan los yaganes retratados fueron negociados por ellos no como actores pasivos, sino como agentes sociales de sus propias circunstancias (Giddens, 1995).

Por ello, consideramos que el estudio de la vestimenta y los adornos corporales se transforman en una herramienta importante para discutir las formas de representación de los distintos grupos, la definición de identidades, las relaciones de poder y el mecanismo que guía nuestra pregunta de investigación: el cambio. Dado que las fotografías etnográficas registran la cultura material de las personas fotografiadas, consideramos que es posible rastrear de manera diacrónica a lo largo de todo el registro fotográfico de los yaganes los cambios que se dieron en la vestimenta y los adornos. De esta manera, es posible rastrear los cambios en la cultura material y en los habitus corporales y las identidades étnicas de estos yaganes, a partir de la adopción -y adaptación- de vestimenta y adornos occidentales y el mantenimiento de vestimenta y adornos autóctonos.

\footnotetext{
${ }^{1}$ Los resultados aquí presentados forman parte de las investigaciones desarrolladas por las autoras en el marco del Consejo Nacional de Investigaciones Científicas y Técnicas (CONICET) y la Asociación de Investigaciones Antropológicas (AIA). Agradecemos especialmente a los museos y archivos y al ARC-FOTAIA, donde recopilamos la muestra fotográfica aquí analizada, gracias a un subsidio del Fondo Nacional de las Artes (FNA). Expresamos nuestra gratitud a Luis Orquera, director de la AIA por su constante apoyo a nuestras investigaciones. Agradecemos a los evaluadores del manuscrito, cuyos comentarios permitieron profundizar y mejorar el escrito.
}

Anuario de la Escuela de Historia Virtual - Año 11 - N 18 - 2020: pp. 158-187. ISSN: 1853-7049 
160 | Ritmos de cambio en la vestimenta y ornamentos de la sociedad Yagán...

A lo largo de este análisis diacrónico esperamos distinguir los distintos ritmos de cambio de esta cultura material y discutir los distintos procesos desarrollados a partir del contacto intercultural con los europeos: adopción plena, adopción parcial (ciclaje), reciclaje y resiliencia. De esta manera, esperamos discutir los procesos de cambio generados mediante la interacción transcultural de este pueblo originario fueguino con la sociedad occidental, a fin de recuperar el rol de la agencia indígena durante ese proceso de contacto.

\section{Cambio cultural, adaptación y resiliencia}

Los procesos de cambio en las sociedades humanas han sido abordados por todas las ciencias sociales, incluyendo la filosofía, la historia, la sociología, las ciencias políticas, la antropología y la arqueología. Sin embargo, estas dos últimas disciplinas son las que se centraron en el estudio de los cambios en la cultura material como temática de investigación y, por eso, sus aportes serán retomados en este trabajo. Debido a sus distintos enfoques temporales, la antropología y la arqueología se han dedicado a analizar los procesos de cambio de maneras diversas, aunque con algunos solapamientos. La antropología, de corte más bien sincrónico, se ha centrado en el estudio de los cambios socioculturales a corto plazo, incluyendo cambios endógenos a las sociedades bajo estudio y cambios debido a situaciones de contacto e interacción entre sociedades -como los surgidos a partir de las situaciones coloniales- (Buscaglia, 2011). Asimismo, los registros antropológicos realizados mediante trabajo etnográfico (textos, fotos, colecciones de artefactos de cultura material, ${ }^{2}$ grabaciones, filmaciones) pueden brindar información sobre numerosos aspectos de la cultura material y modos de vida de las sociedades bajo estudio (Comaroff y Comaroff, 1992).

Por su parte, la arqueología, de corte más bien diacrónico, se ha centrado en el estudio de los cambios a mediano y largo plazo, debido a la posibilidad de generar largas secuencias cronológicas, abarcando varios siglos e incluso milenios, y la dificultad de obtener una resolución cronológica suficiente para evaluar cambios a corto plazo. Sin embargo, la arqueología ofrece importantes aportes al estudio del cambio sociocultural. Por una parte, es la única disciplina que aborda el análisis de artefactos prehistóricos, que no son asequibles en contextos históricos-etnográficos ni contemporáneos y que permiten efectuar valiosas comparaciones. Por otra parte, la arqueología ha desarrollado y aplicado sistemáticamente numerosos conceptos y variables que permiten abordar el estudio de la totalidad de los artefactos culturales producidos y usados por grupos humanos en el pasado (en contextos prehistóricos e históricos-etnográficos) e incluso en el presente (contemporáneos). Estos trabajos sistemáticos generalmente se desarrollan sobre muestras amplias, con el objeto de lograr identificar tendencias significativas que

\footnotetext{
${ }^{2}$ Los artefactos son objetos muebles utilizados, modificados o hechos por el hombre (útiles líticos, la cerámica, armas de metal, etc.) (Renfrew y Bahn, 1998).
}

Anuario de la Escuela de Historia Virtual - Año 11 - Nº 18 - 2020: pp. 158-187. ISSN: 1853-7049 
caracterizan a las prácticas socioculturales en las cuales se manipularon dichos artefactos. Así, se busca señalar tanto las recurrencias que componen a dichas tendencias como sus excepciones y explicar las razones por las cuales se produjeron (Trigger, 1996).

En antropología, el concepto de cambio asociado a los procesos de contacto interétnico atravesó diversos paradigmas, posiblemente por "la continua frustración de los etnólogos para entender adecuadamente la estructura y dinámica de las relaciones entre pueblos de etnias distintas" (Cardoso de Oliveira, 1963, p. 33). Uno de los primeros paradigmas fue el de la escuela norteamericana de los estudios de aculturación (Redfield, Linton y Herskovitz, 1936; Service, 1955), que propuso una visión vertical y unilateral del contacto intercultural como la irremediable adopción de la cultura nueva y dominante (blanca y occidental) y la consecuente pérdida de la cultura autóctona y tradicional (indígena en el caso que nos interesa). Este concepto implicó la comprensión del cambio en términos de transferencia de rasgos culturales entre una sociedad dominante vista como "superior" y una sociedad dominada vista como "débil" e "inferior" (Cardoso de Oliveira, 1963). Esta perspectiva fue ampliamente criticada por sus implicaciones sociopolíticas: la justificación del imperialismo europeo y la concepción de los indígenas como receptores pasivos del cambio cultural, inhabilitados para cualquier tipo de resistencia a la dominación (Service, 1955). Como consecuencia de esa supuesta ausencia de agencia de los sujetos colonizados, se confunden los cambios en el sistema de comportamiento de los indígenas con el cambio en su identidad étnica (Buscaglia, 2011), lo que lleva a inferir, entonces, la extinción de los pueblos indígenas que adoptaron comportamientos y cultura material occidental.

Un segundo paradigma, contrapuesto al proceso unidireccional del cambio propuesto por la noción de aculturación es la transculturación, neologismo que refiere a las transmutaciones culturales que operan en los territorios latinoamericanos cuando entran en contacto la sociedad occidental, los pueblos indígenas y los afrodescendientes (Ortiz, 1983). Así, el concepto de transculturación enfatiza el proceso transitivo de una cultura a otra, que incluye la "desculturación" y la "neoculturación" (Ortiz, 1983, p. 96), reconociendo el proceso de creación de una nueva cultura, que no sería española, indígena ni afrodescendiente, sino una cultura nueva que se expresa tanto en términos ideológicos como materiales (Chaney y Deagan, 1989). Este paradigma fue acusado de esencialista, al diferenciar los aportes de cada cultura a esa nueva cultura como si se tratara de una lista de rasgos que, a pesar del contacto intercultural, fueran inamovibles; asemejándose en ese punto al enfoque aculturacionista (Buscaglia, 2011). Retomando estas críticas, se desarrolló el concepto de culturas híbridas, que avanza en el sentido de la transculturación, pero con el planteo de que en esta fusión multicultural entre lo moderno y lo tradicional tanto los grupos dominantes como los dominados negociaron y aportaron a una nueva cultura, que es heterogénea y siempre está situada en medio de relaciones de poder (García Canclini, 1989). 
162 | Ritmos de cambio en la vestimenta y ornamentos de la sociedad Yagán...

Un tercer paradigma revisionista de los anteriores lo constituye el modelo económico del sistema-mundo (Wallerstein, 1974), que postula que, en el sistema capitalista mundial, existen e interactúan diferentes entidades geopolíticas: núcleos, periferias y semi-periferias. De acuerdo con este modelo, los núcleos son las regiones donde se centraliza la economía y la política, mientras la periferia incluye a las regiones geográficamente distantes, de las cuales se explotan recursos naturales y trabajo humano, y que son económica y políticamente dependientes del núcleo, creando una inequidad estructural. En tal sentido, enfatizan las condiciones socioeconómicas y políticas en las que ocurren los procesos de contacto, a través de la injerencia de los agentes centrales en las regiones periféricas, que impulsarían el cambio de manera unilateral, con la imposición de sus prácticas económicas, políticas y sociales en un ámbito de tal desigualdad que esas condiciones solo podrían ser acatadas. Esta tendencia a pensar dicotómicamente las relaciones entre núcleo y periferia fue ampliamente criticada, ya que caracterizaba nuevamente a las regiones nucleares como agentes activos y coercitivos, mientras las regiones periféricas continuaron siendo pensadas como meras víctimas de la imposición y la explotación (Cusick, 1998). Para enfrentar esas críticas y dar cuenta de la heterogeneidad interna de los centros (en los que existen periferias) y las periferias (en las que existen sectores hegemónicos aliados con los centros), otros autores plantearon un posicionamiento crítico frente a los discursos coloniales y occidentales retomando la concepción de subalternidad (Gramsci, 2000). De esa manera, refirieron a los grupos dominados desde una perspectiva en la cual éstos poseen y ejercen efectivamente su agencia (Comaroff y Comaroff, 1992) e intentan recuperar la voz y la acción de los sujetos subalternizados e invisibilizados (Spivak, 1994), en un contexto de desigualdad que ninguno de los paradigmas anteriores, ni siquiera el de la transculturación, permitía evaluar.

Basándonos en la discusión y aportes ofrecidos por estos paradigmas antropológicos, resulta notorio que tanto el concepto de "transculturación" como el de "culturas híbridas" orientan la mirada respecto de la caracterización del contacto intercultural como un proceso multidireccional, multidimensional y activo por parte de todos los agentes involucrados. Asimismo, en los casos del continente americano, estos procesos de interacción transcultural han ocurrido y ocurren dentro del "sistema-mundo", marcado por situaciones socioeconómicas y políticas no neutrales, señaladas por la explotación, dominación y hegemonía como factores desestabilizantes de los pueblos indígenas y re-estructurantes de las culturas.

A estos conceptos sobre la interacción y los cambios socioculturales se suman también los aportados por la teoría arqueológica, los cuales ofrecen algunos enfoques similares a los anteriores, pero también algunas propuestas innovadoras respecto a cómo pensar el rol de la cultura material en dichas interacciones. La teoría arqueológica incluye marcos teóricos que específicamente se abocaron al estudio y análisis del cambio cultural. Los más antiguos, de inicios del siglo XX, como el difusionismo sustentado por Schmidt y Kossina (entre otros), se centraron en describir la presencia y frecuencia de determinados 
tipos de artefactos de cultura material en distintas regiones arqueológicas, infiriendo "círculos culturales" de influencia de pueblos supuestamente más "avanzados" y "portadores" de estos rasgos, sobre otros más "simples" (Trigger, 1996). Dicho discurso, que mantiene una notoria similitud con la noción de "aculturación", fue profundamente criticado y desechado desde la arqueología moderna por su neta raigambre etnocéntrica y racista. El normativismo fue otro de los paradigmas centrales en la arqueología, propuesto por Willey y Phillips, entre otros, que definieron a las culturas como conjuntos de normas compartidas, que se traducían en la reiteración de atributos similares en los artefactos (Trigger, 1996). En este caso, el criterio para estudiar el cambio cultural fue el cambio en conjuntos recurrentes de dichos atributos (como la morfología de ciertos tipos de artefactos), pero la explicación de por qué ocurrían dichos cambios no fue central en este paradigma.

La primera corriente teórica que podemos indicar como centrada en los cambios culturales fue el procesualismo, cuya definición de cultura como sistema extrasomático de adaptación al medioambiente (Trigger, 1996) implicó un concepto profundamente funcionalista de la cultura material y su vinculación con el ambiente natural. En tal sentido, el procesualismo fue criticado por su noción adaptacionista y teleológica, que supuso originalmente que todo cambio cultural habría tenido una función de adaptación, dejando de lado la explicación de numerosos casos en los que la cultura no facilitó la adaptación de sus productores o usuarios (Trigger, 1996). Las críticas a este paradigma produjeron diversas propuestas que se tradujeron en un amplio abanico de marcos teóricos post-procesuales, como el neoevolucionismo y la teoría de la agencia, que no resumiremos aquí por cuestiones de espacio. De estas, retomamos en este trabajo la teoría de la agencia, debido a que aporta la noción de que la materialidad de la cultura contiene señales de la acción social de sus productores y usuarios, y, en tal sentido, los cambios culturales siempre son activamente negociados por todos los actores sociales, que se convierten en agentes del cambio (Dobres y Robb, 2000). Esta noción es aplicada en nuestras investigaciones tanto para la evaluación de los procesos de formación del registro fotográfico como para el análisis de la cultura material allí registrada (Fiore, 2014; Butto, 2019).

En términos generales, tanto la antropología como la arqueología han reconocido que los cambios en la cultura material pueden ocurrir por diversas causas, tanto endógenas a la sociedad que los produce y/o utiliza (generados por los propios agentes sociales), como exógenas a ella (generados por cuestiones ambientales o por situaciones de contacto e interacción con agentes externos). Cabe notar que esta distinción es analítica, ya que en el caso de que las causas sean exógenas, estas generarán cambios endógenos. Todos estos cambios pueden afectar tanto a la continuidad de producción de determinados tipos de artefactos (sosteniendo la continuación de la producción o marcando su discontinuidad), como a la invención o adopción de otros nuevos (Schiffer, 1972). Tanto la invención como la adopción de artefactos implica un número importante 
164 | Ritmos de cambio en la vestimenta y ornamentos de la sociedad Yagán...

de variables, incluyendo: disponibilidad y utilidad de la materia prima; disponibilidad de técnicas de explotación de la materia prima para la producción del artefacto; morfología, tamaño y propiedades organolépticas del artefacto; funcionalidad utilitaria (práctico-mecánica); valor económico (costo de producción o costo de adquisición según disponibilidad, valor de uso y valor de cambio) y funcionalidad social (utilización como marcador de roles sociales, situaciones de status/prestigio, significación ideológica y simbólica de algunas de sus características - materia prima, morfología, procedencia, etc.-, utilidad para negociación de situaciones sociales, etc.). En tal sentido, la discontinuidad en la producción de un tipo de artefacto puede estar basada en circunstancias relativas a su funcionalidad utilitaria (ej. que ese tipo de artefacto ya no sirva para la función práctico-mecánica que antes cumplía), pero también a su funcionalidad social (ej. que ese tipo de artefacto ya no cumpla su rol como marcador social o que otro nuevo tipo de artefacto -autóctono o foráneo-resulte más deseable para cumplir esta función). Contrariamente, la continuidad en la producción de un tipo de artefacto podrá estar basada, por ejemplo, en que éste siga cumpliendo su funcionalidad utilitaria y/o social; es más, incluso habiendo perdido o no teniendo una importante funcionalidad utilitaria, es posible que se continúe produciéndolo precisamente por su alta valoración en cuanto a su función social. Tal es el caso de la pintura corporal, que se continuó produciendo y utilizando en el siglo XX debido a sus múltiples funciones sociales para situaciones cotidianas, especiales y ceremoniales, incluso cuando ya se había adoptado el uso de ropa occidental (Fiore, 2014). Algunos de los casos bajo estudio en este trabajo se ajustan precisamente a este planteo.

En el caso de la adopción de artefactos en contextos de situación colonial, que implican relaciones sociales de poder estructuradas por la presencia foránea occidental en tierras de pueblos originarios, ocupadas y explotadas de manera invasiva, extractiva y violenta, dicho proceso estuvo marcado por una fuerte desigualdad en las relaciones de poder (Cusick, 1998). Sin embargo, tanto las teorías antropológicas como arqueológicas sobre los procesos de adopción de cultura material coinciden en señalar que, incluso en situaciones de imposición cultural, los artefactos no fueron aceptados de manera pasiva por los nuevos usuarios, sino que dicha incorporación, aunque forzosa, fue muchas veces negociada por los indígenas (Silliman, 2001). A ello se suman las situaciones en las cuales las incorporaciones de artefactos de cultura material fueron voluntarias, estimuladas por el propio interés de los agentes indígenas en determinados ítems de cultura material (Silliman, 2001). A su vez, los procesos de cambio cultural generados por la adopción de artefactos pueden subdividirse en dos: a) la "adopción plena" de un ítem, fundamentada, por ejemplo, en la utilidad de un tipo de artefacto foráneo para cumplir una función de manera más eficiente y/o menos costosa que otro tipo de artefacto localmente utilizado (como la adopción de armas de fuego por distintos pueblos originarios de América para la cacería y la defensa personal); b) la "adopción parcial" de un ítem, fundamentada, por ejemplo, en la utilidad de un componente del objeto o bien de su materia prima pero no de su morfología, que implicarían su reciclado 
(sensu Schiffer, 1972) para una función distinta de la que tenía en su contexto de origen (como la confección de puntas de flecha y raspadores con vidrio de antiguas botellas) o bien su ciclaje lateral (sensu Schiffer, 1972), es decir, su uso para una nueva función, sin necesidad de alterar su morfología. Algunos de los casos bajo estudio en este trabajo se enmarcan en estas distintas formas de adopción cultural. Cabe señalar que este trabajo se basa sobre una ontología centrada en la materialidad como contexto y producto de la agencia humana (Dobres y Robb, 2000; Fiore, 2002; Gel, 1998). Dicha materialidad es crucial para la investigación arqueológica, en tanto permite develar aspectos de las prácticas y negociaciones desarrolladas por los agentes sociales incluso en contextos de los que se carece de información escrita. Para develar parte de dichas prácticas es que utilizamos los planteos de Schiffer (1972) como una teoría de rango medio que aporta conceptos y procedimientos metodológicos para abordar los procesos de producción y transformación de la cultura material y los procesos de formación del registro arqueológico. En tal sentido, la adopción de dicha teoría de rango medio no implica la adhesión a la ontología positivista de la teoría procesual desde la cual fue enunciada, debido a que, precisamente, los conceptos y procedimientos de rango medio son herramientas metodológicas que pueden ser utilizadas desde distintos marcos teóricos con otras ontologías. Esto es lo que nos permite justamente resaltar que los procesos de cambio cultural registrados mediante estas herramientas muestran rastros de las agencias de los indígenas en las diversas formas de negociación (adopción, transformación o rechazo) de los nuevos ítems de cultura material.

A su vez, los conceptos que arrojan luz sobre los procesos de cambio cultural implican inextricablemente a los procesos de continuidad cultural, en tanto que, al focalizar en lo que cambia (en este caso por contacto, interacción e incorporación cultural), resalta por contraste lo que permanece. Dichas permanencias no son neutrales, sino que, por el contrario, reflejan prácticas que, para los agentes que las realizaron/realizan mantuvieron la funcionalidad utilitaria y/o social y/o económica de los objetos involucrados. Así, en la continuidad de uso de determinados artefactos se hallan también rastros de las agencias de las personas que los utilizaron, ya que el mantenimiento de la producción y el uso de estos ítems de cultura material pueden actuar como formas de reafirmación identitaria, de materialización de roles de poder y de resguardo de la memoria, esenciales para la reproducción social incluso en situaciones coloniales que alteraron el orden tradicional de manera profunda e irreversible (Gosden, 1999). En tal sentido, frente a situaciones de dominación, las formas de negociación activa en la incorporación de ciertos artefactos foráneos y las formas de persistencia en el uso de artefactos tradicionales habrían sido vías alternativas para la resistencia, definida como un conjunto de estrategias que reflejan la oposición y el rechazo a una situación social impuesta (McGuire y Painter, 1991). Pero más allá de la resistencia, la continuidad en la producción y uso de artefactos tradicionales habría sido también un vehículo hacia la resiliencia, que implica la capacidad de respuesta del 
166 | Ritmos de cambio en la vestimenta y ornamentos de la sociedad Yagán...

sistema social frente a la adversidad, logrando alguna forma de amortiguación del impacto negativo de las circunstancias, revirtiéndolas total o parcialmente (Glantz y Johnson, 1999). En el caso de las situaciones coloniales como las sufridas en Tierra del Fuego, este concepto arroja luz sobre la capacidad de una sociedad "no solo de resistir a los embates de violencia, control social y apropiación de recursos por parte de otras sociedades, sino también a su habilidad para reponerse parcialmente de dichos embates y mantener la continuidad de algunas de sus pautas culturales y hábitos socioeconómicos tradicionales" (Fiore, 2014, p. 428). Mientras la resistencia se focaliza en la oposición combativa frente al embate desestabilizante, la resiliencia se focaliza en el retorno al equilibrio, sea regresando al sistema previo o reconfigurándolo de acuerdo al nuevo contexto, permitiendo sostener la reproducción social del grupo. Ambas no son excluyentes y pueden haber moldeado diversos aspectos de los procesos de cambio sociocultural.

Ahora bien, debido a que en una misma sociedad pueden operar simultáneamente procesos de cambio y de continuidad cultural, resulta interesante pesquisar cuáles artefactos de cultura material han cambiado (por reemplazo o por adición) y cuáles han permanecido a lo largo del tiempo, ya que permitirá arrojar luz sobre qué aspectos y funciones de los mismos fueron priorizados y mantenidos y cuáles fueron dejados de lado. En tal sentido, sostenemos en este trabajo la noción de que la alta percepción y valoración de las materias primas, morfologías, funciones utilitarias, funciones sociales y/o valores económicos de determinados tipos de artefactos tradicionales generarán la conservación de su producción y uso, por lo cual es esperable que su ritmo de cambio a lo largo del tiempo sea bajo (Fiore, 2012). Contrariamente, si la percepción y valoración de estos aspectos y funciones es baja, se genera la posibilidad de que, ante otros tipos de artefactos de origen foráneo, que tengan características más deseables y/o cumplan estas funciones de manera más efectiva, ocurra un cambio por estos nuevos tipos -siempre y cuando sean asequibles para las poblaciones indígenas-, por lo cual es esperable que su ritmo de cambio a lo largo del tiempo sea comparativamente más alto (Fiore, 2012). Cabe señalar que este segundo escenario es también posible en situaciones de imposición cultural por parte de grupos dominantes que fuercen el uso de determinados artefactos a las poblaciones locales. La distinción entre estas situaciones es netamente contextual y requiere de estudios pormenorizados sobre procesos de uso diacrónico de cultura material, como el que presentamos en este trabajo.

\section{Caso de estudio: los Yagán y su registro fotográfico}

Los Yagán ${ }^{3}$ fueron descriptos como grupos cazadores-pescadores-recolectores con movilidad nómade canoera, cuyos territorios etnográficamente conocidos abarcaban la

${ }^{3}$ Retomamos en este trabajo la forma de auto-denominación que eligieron las comunidades yagán actuales
de Argentina (Comunidad Yagán Paiakoala de Ushuaia) y Chile (Comunidad Yagán Bahía Mejillones de
Puerto Williams). Pero cabe aclarar que esta sociedad fueguina fue especialmente conocida como "Yámana"

Anuario de la Escuela de Historia Virtual - Año 11 - Nº 18 - 2020: pp. 158-187. ISSN: 1853-7049 
porción sur de la Isla Grande de Tierra del Fuego y las islas del archipiélago fueguino hasta el Cabo de Hornos. Su subsistencia se basaba en la caza de lobos marinos, la pesca de peces y la recolección de vegetales, moluscos y huevos, además del aprovechamiento de ballenas varadas (Hyades y Deniker, 2007 [1891]; Lothrop, 1928; Gusinde, 1986 [1937]). Para el aprovechamiento de estos recursos desarrollaron una tecnología específica: las canoas y los arpones, que "permitían obtener cantidad y diversidad de recursos alimenticios de otra manera no accesibles" (Orquera y Piana, 2015, p. 231). El lobo marino constituía la presa más preciada, ya que no solamente aportaba carne y grasa de alto valor calórico, sino que su cuero era aprovechado para la vestimenta y otros instrumentos (Orquera y Piana, 2015). Los campamentos yaganes, de chozas construidas con troncos y hojas, eran habitados por una familia, que constituía la unidad social fundamental, pero podía asociarse transitoriamente a otras familias. Los viajeros que entraron en contacto con esta sociedad señalaron la ausencia de jefes o figuras de autoridad y la división sexual del trabajo semi-igualitaria (Gusinde, 1986 [1937]; Fiore, 2014). La vida religiosa de los Yagán incluía la celebración de múltiples ceremonias en momentos clave de la vida de los individuos: ceremonias de nacimiento, de iniciación mixta, de iniciación exclusivamente masculina, de matrimonio, de curación o shamánicas. Las ceremonias más relevadas por los etnógrafos (Gusinde, 1986 [1937]) fueron el chiejaus, la ceremonia de iniciación mixta a la adultez, y el kina, la ceremonia de iniciación masculina a la adultez.

Las 428 fotografías obtenidas de los Yagán corresponden a las tomas realizadas entre 1881 y 1987 mayormente en Tierra del Fuego por 25 fotógrafos de diversos orígenes, profesiones e intereses. Las primeras fotografías de los Yagán fueron tomadas en 1882 por los fotógrafos que formaban parte de la Misión Científica Francesa al Cabo de Hornos, Jean Louis Doze y Edmond Joseph Payen, quienes ya habían retratado a un grupo de fueguinos -Alakaluf- en 1881 en el Jardin d'Acclimatation de París, donde fueron exhibidos en cautiverio (Fiore y Varela, 2009). Estos dos fotógrafos acompañaron a la Misión Científica Francesa, que debía registrar el paso de Venus frente al sol, y describir la geografía y los habitantes de la región.

Durante las primeras décadas del siglo XX no volvió a haber grandes misiones científicas en la región, por lo que no hubo registros fotográficos de tipo científico. A su vez, los misioneros anglicanos, que estuvieron afincados en la bahía de Ushuaia y otras islas desde 1869 hasta 1916, no parecen haber tenido gran interés en producir imágenes que justificaran su acción evangelizadora, por lo que solo existen escasas imágenes tomadas por los anglicanos (Butto, 2018). Por ello, para los primeros años del siglo XX solo existen fotografías producidas por exploradores viajeros: unas pocas imágenes fueron producidas por el botánico sueco Carl Skottsberg, quien, en su expedición de 1907 hacia las islas Malvinas y Tierra del Fuego, fotografió a varios grupos canoeros; otras

en la bibliografía arqueológica, antropológica e histórica; aunque el término yagán también aparece en algunas fuentes histórico-etnográficas (Piana, 2009). 
168 I Ritmos de cambio en la vestimenta y ornamentos de la sociedad Yagán...

fueron producidas por el etnógrafo alemán al servicio de Argentina Robert LehmannNitsche, quien, como parte de una expedición del Ministerio de Agricultura argentino visitó Tierra del Fuego en 1905 y otras fueron producidas por Charles Wellington Furlong, un coronel y explorador estadounidense que recorrió Patagonia y Tierra del Fuego entre 1907 y 1908.

A partir de 1910 llegaron a Tierra del Fuego misioneros y sacerdotes con intereses etnográficos que permanecieron algún tiempo con los indígenas y tomaron muchas fotografías. Uno de ellos fue el misionero salesiano Alberto De Agostini, quien permaneció varios meses en Ushuaia y Punta Arenas durante sus viajes realizados entre 1910 y 1920. El sacerdote y etnógrafo alemán Martin Gusinde fue quien realizó el trabajo etnográfico y fotográfico más exhaustivo y extendido en el tiempo, realizando cuatro viajes de investigación y conviviendo varios meses con distintos grupos yagán entre 1918 y 1924.

Las fotografías producidas luego de 1930 corresponden a pequeñas expediciones antropológicas, la mayoría conformadas por etnógrafos relacionados con la academia chilena: tal el caso del etnógrafo francés Joseph Emperaire, quien trabajó durante 1950 especialmente entre los Alakaluf -pero tomó fotografías de personas yagán-; el de Alejandro Lipschutz y Grete Mostny, que formaron parte de la Misión Científica Chilena para el Estudio del Indio Fueguino en 1946 y de Omar Ortiz Troncoso, quien trabajó en 1971 con los yaganes de Isla Navarino. Destaca entre estos últimos etnógrafos la figura de la antropóloga franco-estadounidense Anne Chapman, quien, entre 1964 y 1987, realizó un exhaustivo trabajo de campo en territorio fueguino y entrevistó y fotografió a mujeres yagán de Isla Navarino.

A fin de responder las preguntas de investigación fue importante conformar un amplio corpus de fotografías, ya que la investigación de grandes muestras permitiría evitar los sesgos generados por el trabajo con pocas imágenes que pueden reflejar patrones especiales, pero no generales de las personas fotografiadas. Así, al analizar conjuntos amplios de fotografías es posible encontrar tendencias que se aproximen a la situación de las personas fotografiadas (Scherer, 1992; Fiore y Varela, 2009). Profundizaremos en la metodología de estudio en el siguiente apartado.

\section{Metodología: de fotografías y artefactos}

Consideramos que el estudio de un amplio corpus de fotografías permite tener acceso al estudio de la cultura material fotografiada en esas imágenes y, de esa manera, recuperar información acerca de las prácticas sociales de las personas fotografiadas. Esta consideración se desprende del hecho de que la fotografía se constituye en un índice del referente real representado, convirtiéndose así en un artefacto que documenta datos sobre el pasado humano (Fiore y Butto, 2018).

La fotografía fue pensada como una analogía directa de la realidad, que permitía captar las escenas con objetividad, constituyéndose en un mensaje sin código, en un 
testimonio de los hechos acontecidos (Kossoy, 2001; Barthes, 2004). Pero la objetividad fue puesta en entredicho por quienes entendieron que todas las imágenes son simbólicas, ya que son construcciones de sentido, atravesadas por relaciones de poder (Bourdieu, 1979). La concepción de la fotografía como índice tiende un puente entre ambas perspectivas, ya que entiende a la imagen fotográfica como resultado de la conexión física entre el referente real representado, el dispositivo fotográfico y los sesgos del fotógrafo (Butto, 2019). El énfasis está puesto en el carácter de huella de la imagen fotográfica, ya que, sin el referente real, no habría imagen, convirtiendo a la fotografía en testimonio y documento de esa realidad representada (Freund, 2015).

Esa copresencia entre referente, dispositivo fotográfico y fotógrafo se da solo durante el acto fotográfico, pero la evidencia de dicho contacto se extiende por el tiempo de vida de la fotografía como artefacto de cultura material (Fiore y Varela, 2009; Butto, 2019). Esta concepción de la fotografía como artefacto socialmente construido permite desarrollar una "arqueología visual" que rescate tanto la agencia del fotógrafo como la del fotografiado, entendiendo que ese "encuentro de subjetividades" está sujeto a los diferentes intereses y grados de libertad de fotógrafo y fotografiado (Fiore y Varela, 2009). Por lo tanto, es posible captar tanto la visión del fotógrafo como la agencia de la persona fotografiada, desde una perspectiva teórica en la cual ambos son agentes activos durante la toma fotográfica.

En concordancia con esos postulados teóricos desplegamos un abordaje metodológico sistemático, a fin de analizar grandes corpus de fotografías que permitan encontrar patrones de cultura material y prácticas sociales de las personas fotografiadas (Scherer, 1992). Así, este corpus de fotografías fue analizado en tres niveles: el de la fotografía, el de los individuos fotografiados y el de los artefactos fotografiados. En el nivel de la fotografía analizamos: el/la fotógrafo/a, la fecha, el paisaje, el contexto, la cantidad de individuos fotografiados y las estructuras. En el nivel de los individuos fotografiados estudiamos: el género, la edad, el nombre, la postura, la actividad y la vestimenta. En el nivel de los artefactos fotografiados se analizaron: los adornos y los artefactos. Los resultados del análisis de todas estas variables se encuentran publicados en otros trabajos (Fiore y Varela, 2009; Butto, 2019).

Para este trabajo nos hemos centrado en dos elementos clave de la cultura material: la vestimenta y los adornos, que constituyen un conjunto de prácticas corporales, materializadas en modificaciones y accesorios que permiten la comunicación entre diferentes actores sociales (Entwistle, 2000). Dado que la indumentaria implica una serie de modificaciones sobre la materialidad del cuerpo, a través de ella es posible expresar la construcción social de las diferencias, llevando a la identificación de los agentes con sus propios grupos de pertenencia y a la consecuente diferenciación con otros grupos (Eicher y Barnes, 1994). A su vez, esta capacidad identitaria de la vestimenta explica su imposición como una "tecnología de poder" orientada al disciplinamiento de los cuerpos y de las identidades (Foucault, 1988). 
170 | Ritmos de cambio en la vestimenta y ornamentos de la sociedad Yagán...

Estas características refieren al rol activo que desempeña la vestimenta y el adorno como parte integrante de la cultura material y en tanto elementos centrales en los procesos de construcción de identidades (Entwistle, 2000). Consideramos entonces que la vestimenta y los adornos contribuyen a dar forma a la estructura social, ya que los significados de esos objetos son negociados y disputados en las prácticas cotidianas (Giddens, 1995). Así, entendemos que en las fotografías etnográficas bajo análisis la vestimenta y los adornos corporales con que posan los yaganes retratados fueron negociados y disputados, ya que la vestimenta y adornos autóctonos refuerzan por regla general la auto-representación, mientras que la vestimenta y adornos occidentales refieren a la evangelización y "civilización" de los yaganes, es decir, a su inserción en la sociedad occidental (Fiore y Varela, 2009; Butto, 2019).

Por ello, consideramos que el estudio de la vestimenta y los adornos corporales se transforman en una herramienta interesante para discutir las formas de representación de los distintos grupos, la definición de identidades, las relaciones de poder y el mecanismo que guía nuestra pregunta de investigación: el cambio. Dado que las fotografías etnográficas registran la cultura material de las personas fotografiadas, consideramos que es posible rastrear de manera diacrónica a lo largo de todo el registro fotográfico de los yaganes (1881-1987) los cambios que se dieron en la vestimenta y los adornos de los distintos agentes fotografiados. Vale aclarar que el conteo de los artefactos fotografiados no constituye el conteo de artefactos reales (ya que los mismos artefactos pueden haber sido fotografiados múltiples veces), pero sí es un índice de las tendencias recurrentes en el uso de determinados tipos de artefactos (Fiore, 2014). De esta manera, es posible rastrear los cambios que se dieron en estos elementos de la cultura material y los consecuentes cambios que se dieron en los habitus corporales y las identidades étnicas de estos yaganes, a partir de la adopción -y adaptación- de vestimenta y adornos occidentales.

\section{Diacronía de los cambios en vestimenta y adornos corporales}

En este apartado analizaremos el corpus de 428 fotografías de Yaganes, tomadas por un total de 25 fotógrafos entre 1881 y 1987 mayormente en Tierra del Fuego. Centraremos nuestro análisis en el origen indígena u occidental de la vestimenta y los adornos que visten esos individuos, a fin de discutir de manera diacrónica la adopción de ítems de cultura material occidental, así como el mantenimiento de objetos de cultura material tradicional.

En el corpus total de fotos, se retrata un total de 1574 personas yagán. Encontramos que la mayoría de esos Yaganes fotografiados visten ropas occidentales (81\%), mientras una minoría viste ropa autóctona $(10 \%)$ o no viste ropa en absoluto, es decir, posan desnudos (8\%) (Ver Tabla 1). La desnudez constituye un rasgo que fue observado por muchos viajeros en Yaganes de ambos géneros e incluso en niños, conformando un habitus corporal tradicional (Darwin, 2000 [1839]; Hyades y Deniker, 2007 [1891]). Por 
otro lado, entre la vestimenta tradicional indígena las que adquieren mayor importancia son las capas (6\%), que consistían en una piel de lobo marino o guanaco "demasiado pequeña para poderse envolver con ella. La usaban colgando de los hombros o, si no, sujeta al cuerpo como protección contra el viento" (Bridges, 1951, p. 56) y los cubresexos (3\%), que constan de "un corto delantal hecho de piel de nutria" (Bridges, 1951, p. 56). Dentro de las vestimentas occidentales, las de mayor importancia son las chaquetas y pantalones $(26 \%)$ y las camisas y polleras $(23 \%)$, seguidas de otras prendas como las camisas y pantalones $(8 \%)$, las mantas $(9 \%)$, los vestidos $(9 \%)$, los pantalones $(4 \%)$, las polleras $(1 \%)$ y los trajes $(1 \%)$. Según muchos viajeros que entraron en contacto con los Yagán, estos indígenas pedían insistentemente ropas a los viajeros que recorrían los canales (Fitz Roy, 1839; Darwin, 2000 [1839]), e incluso para algunos autores "codiciaban mucho los tejidos de lana" (Hyades y Deniker, 2007 [1888], p. 31). Entre la vestimenta occidental resulta interesante el uso de las mantas, de clara factura foránea, pero que se usaron a la manera de las capas de lobo marino: como cobertor de espalda y hombros y que aparentemente era lo que preferían al negociar con los exploradores (Fitz Roy, 1839).

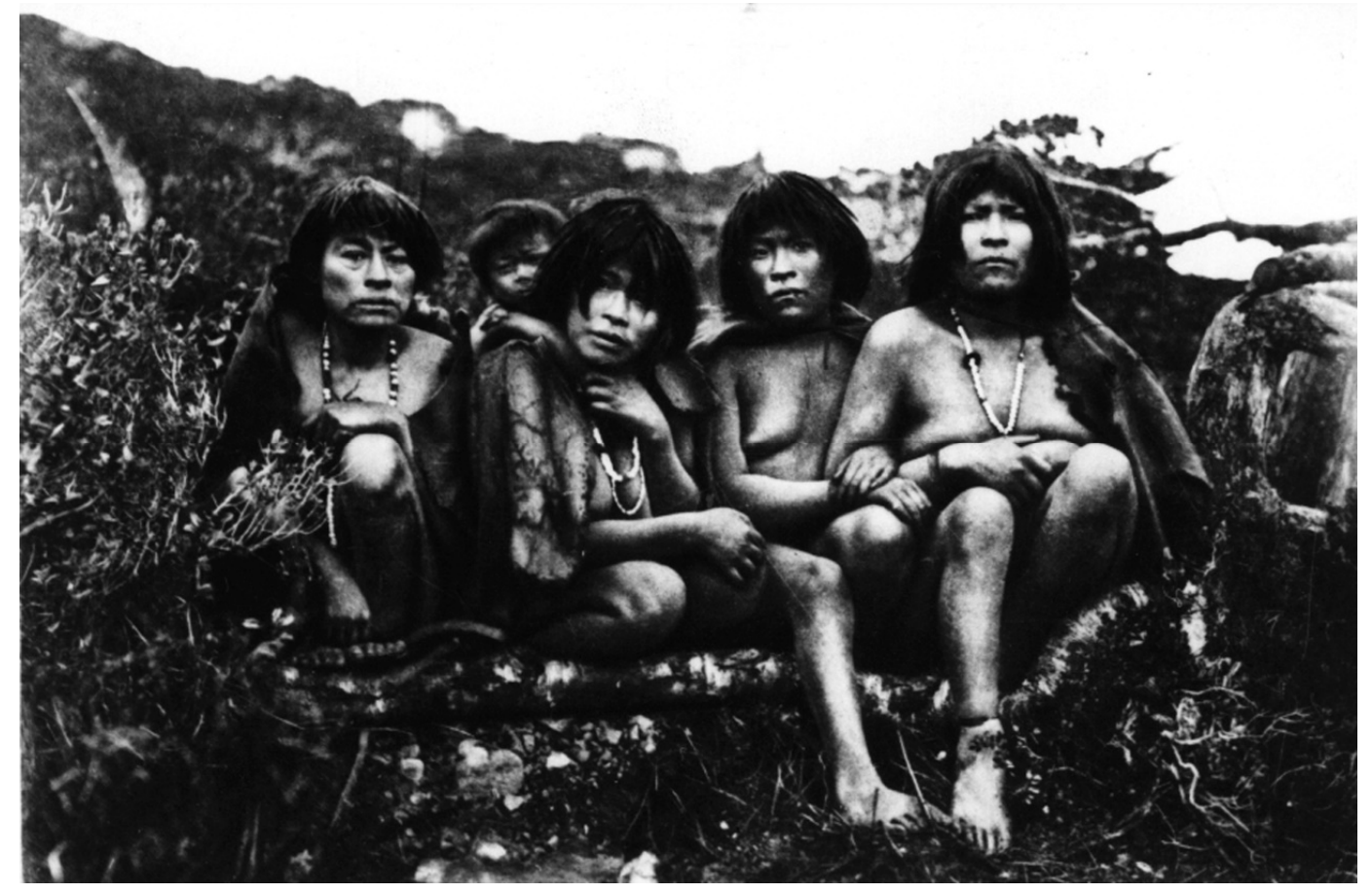

Imagen 1. Mujeres y niños yagán vistiendo capas de lobo marino, mantas occidentales y collares. Jean Louis Doze y Edmond Joseph Payen, Misión Científica Francesa al Cabo de Hornos, 1882-1883.

Respecto de los adornos corporales, la mayoría de los individuos yagán fotografiados no porta ningún tipo de adorno (76\% de 1574 individuos fotografiados). Pero, a diferencia de la vestimenta, entre los individuos que sí portan adornos, la gran mayoría son adornos indígenas: pintura corporal (40\% de 557 ornamentos representados), diademas $(21 \%)$, tobilleras $(5 \%)$, brazaletes $(5 \%)$, máscaras $(2 \%)$ o palillos de nariz $(1 \%)$. La pintura facial y corporal fue mencionada por la mayoría de los viajeros que entraron 
172 | Ritmos de cambio en la vestimenta y ornamentos de la sociedad Yagán...

en contacto con los Yagán (Fitz Roy, 1839; Hyades y Deniker, 2007 [1891]; Gusinde, 1986 [1937]). También llamó la atención de los viajeros el uso de collares "hechos de huesos de patas de pájaros, especialmente de cormorán, o bien de conchitas de color violáceo" (Hyades y Deniker, 2007 [1888], p. 31) y el uso de aros de cuero de lobo marino en las muñecas y en los tobillos. Escasos individuos usan adornos occidentales, como medallas $(1 \%)$, anteojos $(0,5 \%)$, anillos $(0,1 \%)$, pendientes $(0,1 \%)$ y relojes $(0,1 \%)$. El adorno más significativo son las medallas religiosas, que podrían señalar el contacto de esos individuos con viajeros occidentales que se las hubieran regalado, ya que no hay registros de que los misioneros anglicanos entregaran medallas como sí lo hacían los salesianos (Bridges, 2005 [1948]).

Al analizar la asociación de la vestimenta y los adornos encontramos diferentes comportamientos respecto de esta cultura material. Para el caso de los adornos autóctonos parecen existir dos comportamientos diferenciados: algunos adornos indígenas se continuaron usando solo con vestimentas autóctonas y otros se usaron aún con vestimentas occidentales. Los brazaletes y tobilleras de cuero parecen responder al primer grupo, ya que aparecen asociados especialmente a las capas y los cubresexos: las personas que visten capas usan brazaletes ( $2 \%$ de 87 individuos con capas) y tobilleras (1\%) y los individuos con cubresexos también usan brazaletes ( $16 \%$ de 61 individuos en cubresexos) y tobilleras (1\%). Por otro lado, los collares, las diademas y la pintura corporal parecen responder al segundo grupo de adornos, ya que fueron usados tanto con capas y cubresexos, como con camisas, chaquetas, pantalones, polleras y vestidos. Así, los Yagán que visten prendas autóctonas -capas y cubresexos- usan collares (17\% de 187 yagán en prendas autóctonas), pintura corporal (10\%) y diademas (5\%); pero los Yagán que usan prendas foráneas también usan collares (3\% de 1438 individuos con prendas foráneas), pintura corporal (14\%) y diademas (7\%). De esta manera, las frecuencias de uso de estos adornos son similares en ambos casos, aunque mayores en los individuos con prendas autóctonas, reforzando la asociación entre vestimenta y adornos típicamente yagán. Las máscaras de cuero utilizadas en la ceremonia de iniciación llamada kina también parecen pertenecer al segundo grupo de adornos, ya que fueron usadas por Yaganes que visten cubresexos (36\% de 11 individuos con máscaras) o pantalones -arremangados- (64\%). Ambas prendas fueron usadas de la misma manera: dejando entrever el cuerpo casi desnudo y pintado con pintura, especialmente para la participación en esta ceremonia (Gusinde, 1986 [1937]). 


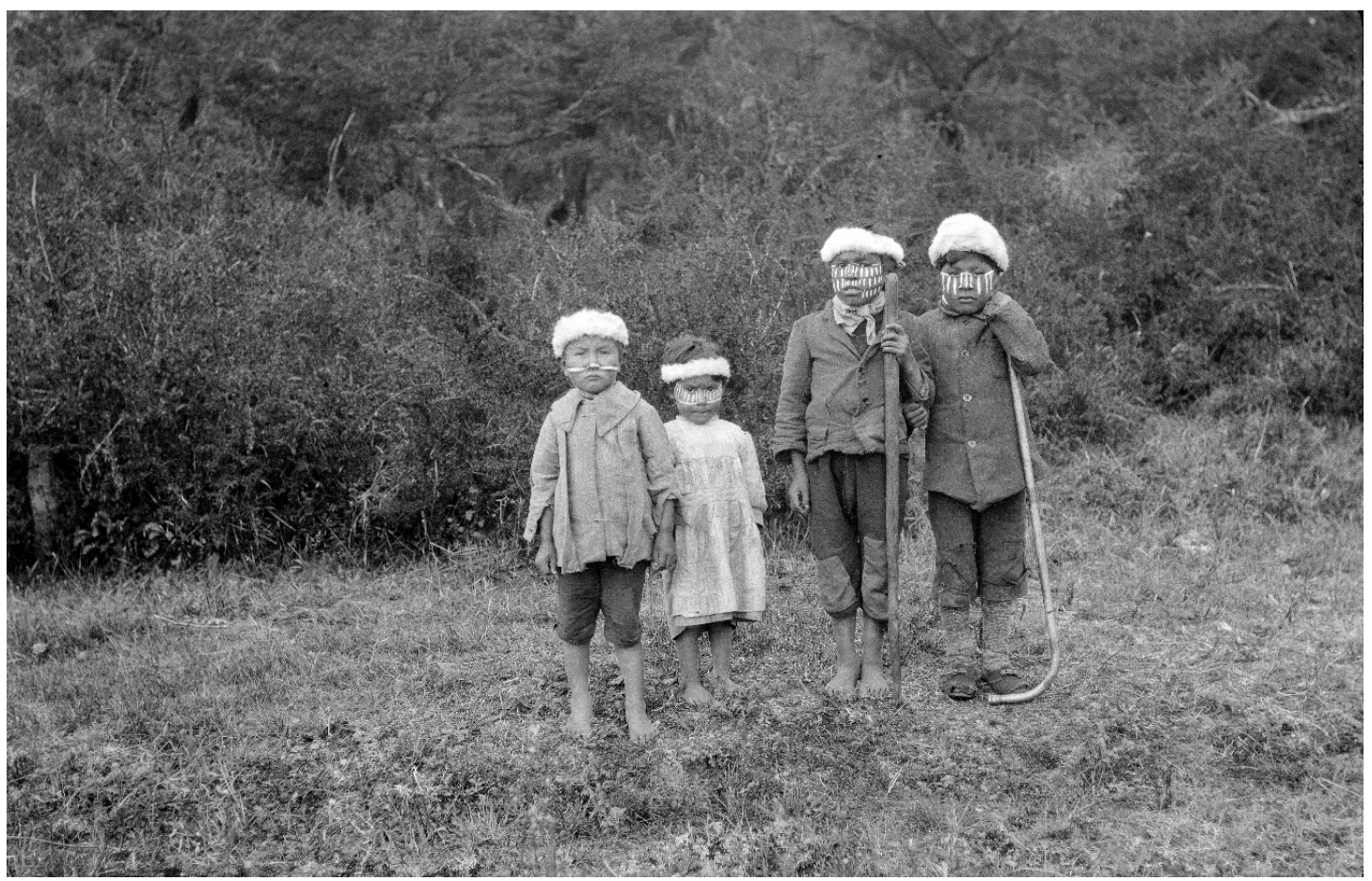

Imagen 2. Niños yagán de Isla Navarino con ropa occidental y pintura facial tradicional.

Martin Gusinde, 1922.

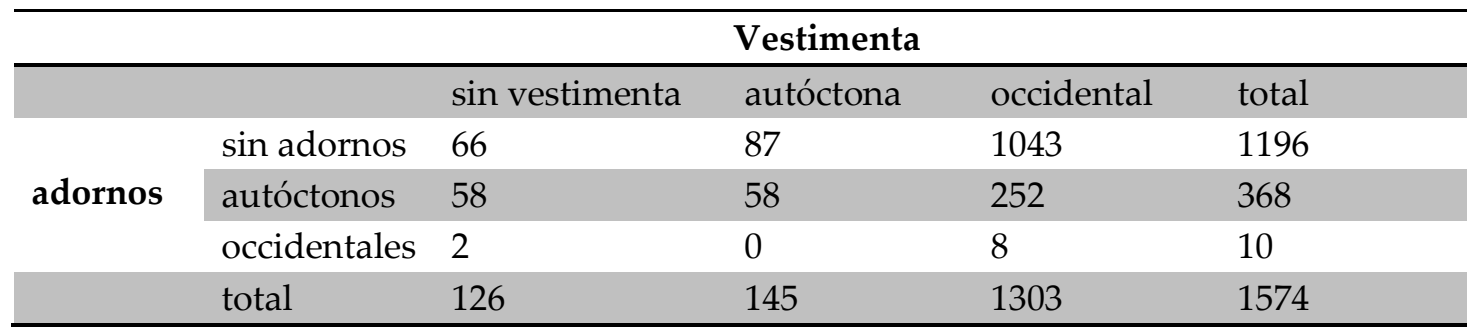

Tabla 1: Cantidad y tipo de vestimenta y adornos de las personas yaganes fotografiadas.

Por otro lado, los adornos occidentales parecen responder a una asociación casi exclusiva con vestimentas también occidentales. Los anteojos con chaqueta y pantalón ( $\mathrm{N}=1$ de 3 individuos con anteojos), camisa y pollera $(\mathrm{N}=1)$ o vestido $(\mathrm{N}=1)$, mientras el único reloj y el único pendiente fotografiados son usados por dos mujeres yagán que visten camisa y pollera. En cambio, las medallas religiosas fueron usadas tanto por personas yagán que vestían camisa y pollera (60\% de 5 individuos con medallas), como por otras personas yagán que llevaban medallas sobre su cuerpo desnudo (40\%). Esto sugiere que estas medallas religiosas pudieron haber sido usadas por personas que no vivían en contacto cotidiano con los blancos y que mantenían importantes rasgos tradicionales de la cultura yagán, como la desnudez (Butto, 2018). 
174 | Ritmos de cambio en la vestimenta y ornamentos de la sociedad Yagán...

$\mathrm{Al}$ analizar estos resultados de manera diacrónica, encontramos distintos patrones de mantenimiento de la vestimenta y adornos autóctonos, así como de adopción de vestimenta y adornos occidentales. Analizaremos esos resultados por década, que corresponden usualmente al registro de ciertos fotógrafos a los que ya nos referimos en el caso de estudio.

Las primeras fotografías de los Yagán se tomaron en la década 1880-1890. Se tomaron un total de 138 fotos, de las cuales 136 fueron tomadas por los fotógrafos franceses Jean Louis Doze y Edmond Joseph Payen entre 1882 y 1883 y solo dos fotografías fueron tomadas por el fotógrafo alemán G. Gunther en 1881. Doze y Payen formaban parte de una Misión Científica Francesa que estableció una base de observación en bahía Orange (isla Hoste, actualmente en Chile) con objetivos meteorológicos, geográficos y geológicos. Sus observaciones etnográficas fueron escritas en textos altamente estructurados de acuerdo con ítems descriptivos tales como características físicas, lenguaje, conducta, hábitos, etc. Esta visión sistemática de la sociedad Yagán se tradujo en parte en las fotografías tomadas por esta misión, que buscaron producir una representación de estilo empirista o "naturalista", orientada por un afán más bien descriptivo (Fiore y Varela, 2009). Así, las tomas enfatizan en algunas características culturales que podían considerarse como tradicionales de los Yagán, a fin de mostrar a los indígenas en su estado "prístino". Sin embargo, también retrataron a los Yagán utilizando vestimenta y ornamentos occidentales, e incluso fotografiaron a quienes se habían incorporado a las misiones anglicanas, mostrando el proceso de occidentalización de sus costumbres. En estas fotografías se retrata un total de 453 personas yaganes, entre las cuales la mayoría viste ropas occidentales $(\mathrm{N}=245)$, una gran parte posa desnudo $(\mathrm{N}=116)$ y otras visten ropas autóctonas $(\mathrm{N}=92)$. La gran mayoría no visten adornos $(\mathrm{N}=318)$, pero cuando los visten son autóctonos $(\mathrm{N}=135)$. Entre las características más llamativas de las fotografías de esta década podemos resaltar que es el momento en que más personas yagán fueron retratadas desnudas, número que no se repetirá nunca más en la secuencia de fotografías. 


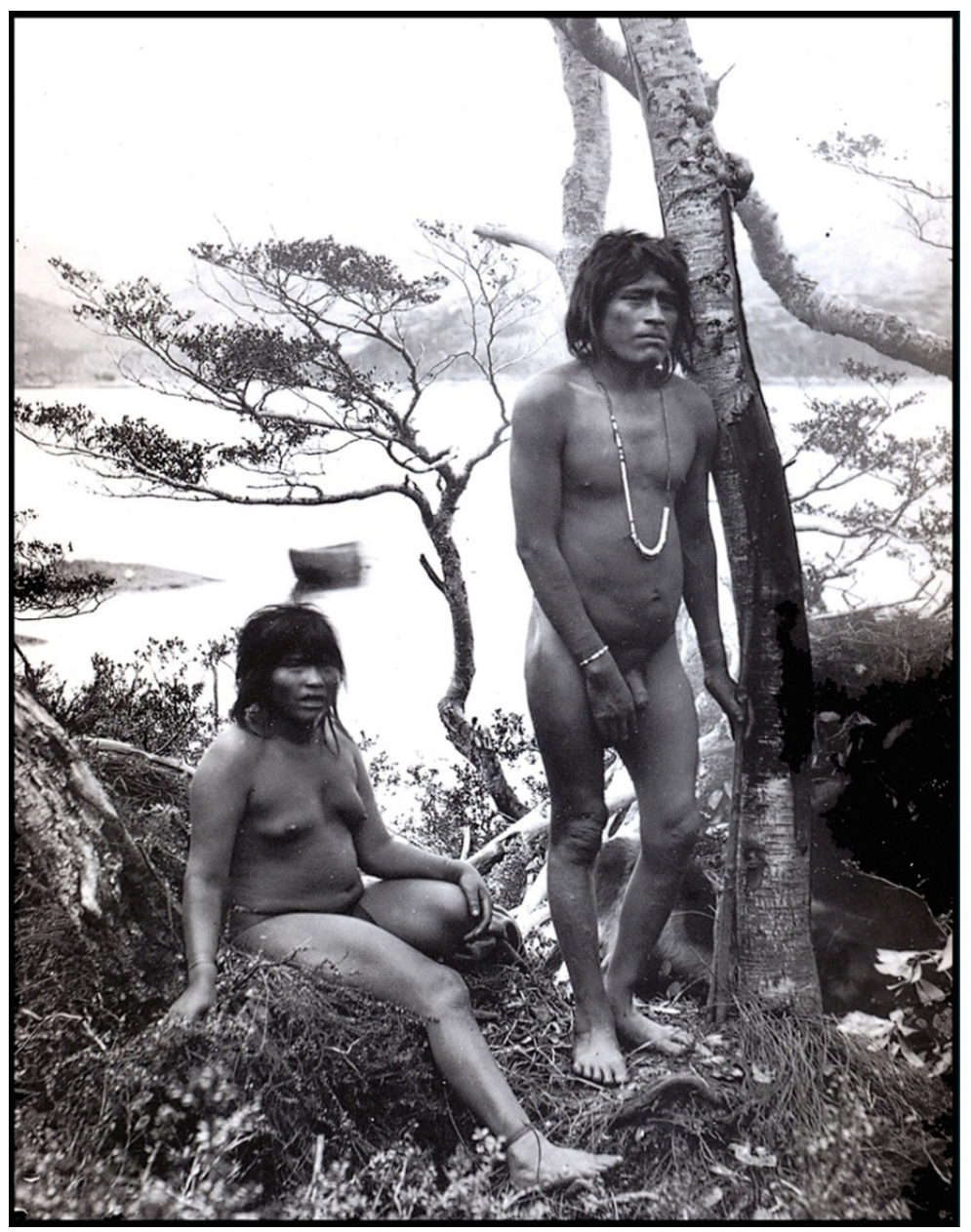

Imagen 3. Athlinata desnudo y Yaelengu Kipa con cubresexo, ambos vistiendo adornos autóctonos. Jean Louis Doze y Edmond Joseph Payen, Misión Científica Francesa al Cabo de Hornos, 1882-1883.

En la década de 1890 se obtuvieron solo dos fotografías, una de ellas (de autor desconocido) retrata un grupo de jóvenes y niños yagán en una misión anglicana y otra del fotógrafo Cañas Pinochet retrata una familia frente a una choza. En ambas fotos todos los yaganes retratados $(\mathrm{N}=22)$ visten ropas occidentales y llama la atención que ninguno de ellos lleve ningún adorno, ni autóctono ni occidental.

Un total de 34 fotografías fueron obtenidas en la década de 1900, la mayoría por parte de exploradores: el estadounidense Charles Furlong, el alemán Robert Lehmann-Nitsche y el inglés William Barclay. Furlong, un coronel de Estados Unidos, visitó la región de Tierra del Fuego en el verano de 1907-1908. Sus publicaciones posteriores al viaje se destacan por la alta estructuración de los datos presentados (organizados con numerosos subtítulos), y por el énfasis en la influencia del clima sobre el desarrollo de las sociedades indígenas. Sus fotografías reflejan distintas escenas de la vida cotidiana de los Yagán, con epígrafes que aportan datos sobre la situación que se estaba documentando (por ejemplo, que una persona estaba en duelo). En tal sentido, si bien los sujetos miran a la cámara, no parecen ser escenas enteramente posadas (Fiore, 2002; Fiore y Varela, 2009). 
176 | Ritmos de cambio en la vestimenta y ornamentos de la sociedad Yagán...

En el caso de Barclay, un inglés que visitó la región acompañando a una misión del Ministerio del Interior argentino en 1902, su estadía fue solamente de 13 días. Barclay generó sin embargo algunas tomas sumamente informativas sobre los Yagán, en las cuales se observan tanto el uso de ornamentos ceremoniales como la actividad del manejo de una canoa, asociada en la costa a una acumulación de valvas, típica del consumo de moluscos por esta sociedad. El caso de Lehmann-Nitsche es todo lo opuesto, ya que en 1902 realizó en un destacamento policial de cercanías del río Fuego el registro de medidas antropométricas y retrato de una joven mujer Yagán llamada Anolsh (Lehmann-Nitsche, 1915). El autor señaló que Anolsh, junto a cuatro jóvenes Selk'nam, "habían sido arrebatadas a sus antiguos dueños, los Onas, en una de las sangrientas luchas con que los avances de la llamada civilización blanca siguen manchando sus pretendidas tendencias de progreso" (Lehmann-Nitsche, 1915, p. 185). Las implicaciones históricas y sociales de la presencia de Anolsh en dicho destacamento exceden la discusión de este trabajo (ver detalles en Fiore y Varela, 2009); pero resulta relevante remarcar aquí que la producción de la fotografía fue realizada en un contexto profundamente trastocado por la invasiva presencia occidental en Tierra del Fuego, que implicó, entre otros efectos, que una joven Yagán se encontrara trasladada a un destacamento de operación estatal, emplazado en territorio Selk'nam.

En estas fotos se retrata un total de 212 personas yagán, entre las que predominan las vestimentas occidentales $(\mathrm{N}=186)$, pero también aparecen vestimentas autóctonas $(\mathrm{N}=$ 22) y unas pocas personas desnudas $(\mathrm{N}=4)$. La gran mayoría de esas personas, incluso las que se encuentran desnudas, no porta adornos. Sin embargo, de las personas con vestimenta autóctona seis usan adornos autóctonos, combinando vestimenta y adornos tradicionales. Por otro lado, de las personas con vestimenta occidental la gran mayoría no usa adornos $(\mathrm{N}=180)$ y la misma cantidad de personas que llevan adornos autóctonos $(\mathrm{N}=3)$, llevan adornos occidentales $(\mathrm{N}=3)$.

En la década de 1910 se concentran algunas de las fotos $(\mathrm{N}=13)$ obtenidas por el misionero salesiano Alberto María De Agostini durante sus visitas a las misiones salesianas de Tierra del Fuego. Las imágenes de este misionero representan escenas étnicas, que, en muchos casos, fueron verdaderas puestas en escena, construidas como parte de la propaganda salesiana acerca del éxito de su labor misionera (Alvarado et al., 2007; Fiore y Varela, 2009). En estas fotos se retratan un total de 49 personas yagán, de las cuales la mayoría viste ropas occidentales $(\mathrm{N}=35)$, otros visten ropas autóctonas ( $\mathrm{N}$ = 14) y ninguna persona posa desnuda. Llamativamente, de esas personas con ropas occidentales, la mayoría usa adornos autóctonos $(\mathrm{N}=31)$ y ninguno usa adornos occidentales. Por otro lado, de las personas que visten ropas autóctonas, la mitad $(\mathrm{N}=7)$ lleva adornos autóctonos y la otra mitad no lleva ningún adorno. Tanto la ausencia de desnudez como el énfasis en los adornos indígenas (tanto con vestimenta indígena como occidental) pueden deberse al interés del fotógrafo en lograr imágenes exóticas de los Yaganes, aunque adecuadas a la ética misionera (Butto, 2018). 
Aunque no corresponda a una década, el período de tiempo que abarca a las visitas del sacerdote y etnógrafo alemán Martin Gusinde, es decir entre 1918-1924, deben ser tomadas como un conjunto, en parte porque no conocemos las fechas exactas de muchas de sus fotografías y en parte por la cantidad de imágenes que produjo y la coherencia interna de ese corpus. En las 190 fotografías obtenidas en ese lapso temporal se incluyen 185 fotografías de Gusinde y 3 fotografías de Samuel Lothrop, un etnógrafo estadounidense que retrató algunos yaganes en 1924. Gusinde fue el fotógrafo más prolífico de la región, produciendo más de 700 tomas fotográficas de las tres sociedades fueguinas, así como de paisajes de la región (Alvarado et al., 2007; Fiore y Varela, 2009 y datos del Archivo Fotográfico de Imágenes Etnográficas de Fuego-Patagonia, Asociación de Investigaciones Antropológicas, Buenos Aires). Debido al gran corpus fotográfico producido, se observa más de una tendencia en las imágenes, las cuales incluyen representaciones naturalistas, escenificaciones posadas, registros antropométricos de frente y perfil y representaciones del avance de la cultura occidental entre los Yagán. Estas últimas, además, fueron por lo general las que menos circularon, dado que Gusinde estaba muy interesado en representar a los Yagán con sus hábitos culturales más tradicionales, razón por la cual negoció con algunas personas que posaran utilizando sus ropas autóctonas (lo cual interesantemente implica que aún tenían acceso a dichas vestimentas, ver Fiore, 2002) y evitó todo lo posible la publicación de fotografías en las cuales se observaran rasgos de cultura material occidental (Fiore, 2002; Fiore y Varela, 2009). Aún frente a estos sesgos y negociaciones, las fotografías tomadas por Gusinde muestran tendencias diferenciales bien marcadas entre los Selk'nam, los Alakaluf/Kawésqar y los Yagán, lo cual indica que las agencias de estos sujetos tuvieron llegada al propio registro fotográfico de sus prácticas (Fiore y Varela, 2009; Butto, 2019).

En el caso de Lothrop, que también visitó Tierra del Fuego en 1924, la producción fotográfica es escasa, pero sumamente informativa, en tanto que en las fotos que se le atribuyen -publicadas en sus propios trabajos etnográficos- ${ }^{4}$ se dedicó a registrar actividades tecnológicas desarrolladas por los Yagán, tales como tareas de trenzado o de confección de artefactos de corteza (Fiore y Varela, 2009).

En estas fotografías se retrata a un total de 725 personas yagán, de las cuales la gran mayoría ( $\mathrm{N}=706)$ viste ropas occidentales, unas pocas personas visten ropas autóctonas $(\mathrm{N}=15)$ y solo 4 personas posan desnudas. Dentro de este gran corpus de fotos, resaltan las siguientes tendencias: las personas con ropas occidentales en su mayoría no llevan ningún adorno $(\mathrm{N}=526)$, pero, si llevan algún adorno, es mayormente autóctono $(\mathrm{N}=$ 178) y muy pocos llevan adornos occidentales $(\mathrm{N}=2)$. En el caso de las personas con vestimenta autóctona, casi la mitad no llevan adornos $(\mathrm{N}=8)$ y la otra mitad lleva adornos autóctonos $(\mathrm{N}=7)$. Mientras en el caso de las personas que posan desnudas, llamativamente la mayoría llevan adornos occidentales $(\mathrm{N}=2)$ y solo una lleva un

\footnotetext{
${ }^{4}$ Lothrop también publicó fotos tomadas por otros fotógrafos, pero siempre indicando dicha autoría en los epígrafes de las imágenes.
} 
178 | Ritmos de cambio en la vestimenta y ornamentos de la sociedad Yagán...

adorno autóctono. De esta manera, resultan especialmente llamativos dos casos contrapuestos: por un lado, el de una foto en la que aparecen dos niños desnudos vistiendo adornos occidentales, específicamente una medalla religiosa que podría marcar el intercambio con algún misionero (Butto, 2018) y, por otro lado, las 178 personas yagán que visten prendas occidentales con adornos autóctonos ceremoniales como pintura corporal, diademas y máscaras.

Un total de 21 fotografías se obtuvieron en la década de 1940, especialmente por parte de etnógrafos franceses como Joseph Emperaire, chilenos como Grete Mostny y Alejandro Lipschutz y alemán como Roberto Gertsmann. Las imágenes de estos etnógrafos responden a su interés antropológico, con una representación centrada en la cotidianeidad de los Yagán, retratando escenas familiares y espontáneas en las chozas y casas habitadas por los Yaganes de Isla Navarino. Estas imágenes registran un total de 51 personas yagán, de las cuales la gran mayoría viste ropas occidentales $(\mathrm{N}=48)$, otros pocos visten ropas autóctonas $(\mathrm{N}=2)$ y solo una persona posa desnuda. Llamativamente, ninguno de esos individuos lleva adornos.

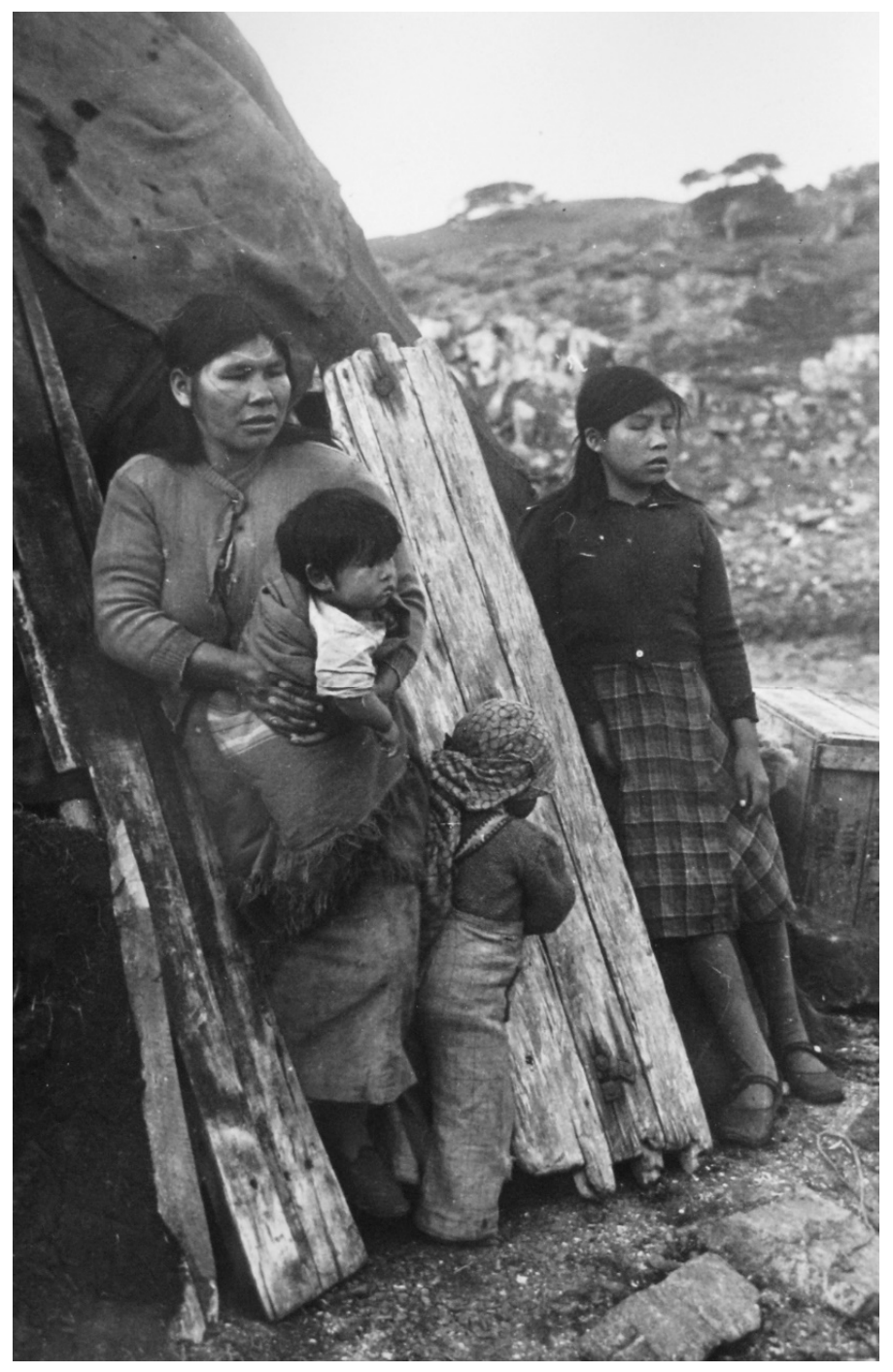

Anuario de la Escuela de Historia Virtual - Año 11 - N 18 - 2020: pp. 158-187. ISSN: 1853-7049 
Imagen 4. Mujer yagán con hijos, todos vistiendo ropa occidental. Grete Mostny, 1946.

No contamos con registro fotográfico de la década de 1950 y en la década de 1960 solo se registran 2 fotografías, obtenidas por la etnógrafa franco-estadounidense Anne Chapman, en las cuales se registran 3 personas yagán. Esas personas visten ropas occidentales y la mayoría $(\mathrm{N}=2)$ no llevan adornos, a excepción de una de ellas, una mujer yagán que viste pendientes occidentales.

Tampoco contamos con registro fotográfico de la década de 1970 y para la década de 1980 se registran solo 3 fotografías de la misma etnógrafa, en las cuales se retrata a 4 personas yagán con ropas occidentales sin ningún tipo de adorno.

\section{Discusión y reflexiones finales}

Al desarrollar una lectura transversal de los resultados diacrónicos encontramos que desde el inicio del proceso se registran en las fotografías etnográficas dos tendencias muy claras. La primera tendencia es una alta proporción de vestimenta occidental sin adornos; la cual se mantiene, con altibajos, a lo largo de toda la secuencia fotográfica. Sin embargo, la segunda tendencia que aparece también al inicio de la secuencia son los considerablemente frecuentes casos registrados de desnudez y los casos de vestimenta autóctona, ambos con adornos autóctonos o sin adornos; tendencia que sí se reduce drásticamente a partir de la década de 1890. El caso de la desnudez no se trataría de una ocurrencia aislada documentada solo por los fotógrafos de la Misión Científica Francesa en la década de 1880, sino de un hábito corporal de los Yagán, registrado en fuentes escritas, dibujos y grabados legados por los viajeros, exploradores y colonizadores que entraron en contacto con este pueblo desde el siglo XVII en adelante (ver referencias en Orquera y Piana, 2015).

Existe, sin embargo, un caso paradigmático de proporciones invertidas en la década de 1910-1919. En esta década se registra la mayor proporción de vestimenta occidental combinada con el uso de adornos autóctonos; esta tendencia se repite (con alta frecuencia, aunque en menor proporción) en el período 1918-1924. Existe la posibilidad de que junto con el proceso de occidentalización creciente haya habido también un proceso de negociación creciente por parte de las personas fotografiadas, que posaran con ropas occidentales a pedido de los fotógrafos: ambos factores generarían una potencial equifinalidad en el registro fotográfico, ya que ambas causas resultarían como efecto en una gran proporción de tomas de personas Yagán con vestimenta/ornamentos occidentales. Sin embargo, la tendencia observada es heterogénea, en tanto que mientras hay alta proporción de registro de vestimenta occidental, los ornamentos registrados son en gran proporción autóctonos. Consideramos que esta particular tendencia puede responder a un doble proceso, construido por las agencias de los sujetos que interactuaron durante la toma fotográfica: los fotógrafos y los sujetos fotografiados. Por 
180 | Ritmos de cambio en la vestimenta y ornamentos de la sociedad Yagán...

una parte, los intereses propagandísticos de un fotógrafo perteneciente a una orden católica Salesiana como De Agostini -en 1910 en adelante- y los objetivos antropológicos del etnógrafo y sacerdote de la orden católica del Verbo Divino como Gusinde -de 1918 en adelante-, habrían estimulado el registro de estas prácticas debido a su "exotismo", tanto para intentar representar su estado de vulnerabilidad, y justificar así la intervención misionera religiosa, como para intentar representar su estado "prístino", como para confirmar la validez antropológica de las observaciones sobre dichas culturas “arcaicas"(Fiore y Varela, 2009; Butto, 2019). Por otra parte, si la influencia de estos fotógrafos hubiera sido unívoca y homogénea, el retrato de rasgos culturales autóctonos no se habría restringido solo a los ornamentos, y se habría extendido a la desnudez (que no fue registrada entre los Yagán para esta época) y/o al uso de ropas autóctonas (que fue una tendencia muy minoritaria).

Aquí se abre entonces el espacio para reconocer el proceso histórico, social y cultural que estaba acaeciendo entre los Yagán desde 1910 en adelante: las fotografías estarían demostrando que, incluso si se favorecía o negociaba el uso de ornamentos tradicionales para el momento de la toma, el uso de la ropa tradicional (y menos aún de la desnudez) ya no eran prácticas habituales -ni negociables-. Más aún, la occidentalización evidenciada en esta sección de la muestra de imágenes bajo estudio es verificada en el proceso histórico: se trató de un proceso de transformación cultural efectiva, que continuó hasta el siglo XXI.

En estas transformaciones encontramos la convivencia de distintos procesos, que refieren en última instancia a esos diversos ritmos de cambio en la adopción de la cultura material occidental y el mantenimiento de la cultura material autóctona.

Encontramos una adopción plena de la vestimenta occidental, a pesar de no ser enteramente funcional ni "adaptativa", ya que muchas fuentes indican que los yaganes se mojaban al movilizarse en las canoas o al pescar y cazar en el mar, y al permanecer con la ropa mojada pegada al cuerpo contraían mayores enfermedades que con sus capas tradicionales (Orquera y Piana, 2015). Por lo tanto, consideramos que otros valores no funcionales pesaron más en la adopción de esta vestimenta, como la coerción, el aleccionamiento social y los discursos ideológicos emitidos por los nuevos agentes hegemónicos de origen occidental (como misioneros, militares, agentes del estado, estancieros, etc.), cuyo control de tierras, caminos, aguas y recursos, ejercieron fuertísimas presiones sobre la población yagán.

También se registra como caso de posible adopción plena, la adopción de medallas religiosas por parte de los yaganes. Este se conforma como un caso excepcional no solamente por su muy escasa proporción, sino también por la asociación del uso de las medallas con la desnudez (en el caso de dos niños que las llevan colocadas, en una misma foto obtenida por Gusinde, pero no publicada). Ahora bien, dado que estos casos se sustentan en muy poca evidencia, esta posible adopción de este ornamento occidental de naturaleza religiosa podría claramente tratarse de una imposición momentánea para la toma fotográfica. Por lo tanto, al carecer aún de otros datos de corroboración respecto 
de su uso (por ejemplo, de documentos que informen sobre una práctica asociada al bautismo o comunión de los niños en cuestión), no podemos confirmar certeramente que su adopción haya sido realmente plena. Más aún, si bien es posible que se hubiera adoptado el artefacto de manera plena, porque no ha sido reformatizado -utilizándolo como materia prima para fabricar otro objeto-, destacamos que ello no implica la adopción ni aceptación de la creencia católica por parte de los niños que lo portan, ni por sus familias. Sin embargo, lo que refleja esta foto es el claro proceso de contacto con la sociedad occidental, vehiculizado en uno de sus agentes de transformación más contundentes: la iglesia católica.

Encontramos a su vez un caso paradigmático de adopción parcial de vestimenta occidental modificada para "sostener" en el cuerpo las pinturas ceremoniales. Se trata de varios individuos que en la ceremonia del kina utilizan pantalones arremangados a la altura de las rodillas, a fin de poder pintar el resto del cuerpo (piernas, torso, brazos y cara) con la pintura corporal ceremonial correspondiente al espíritu que personifican (Gusinde, 1986 [1937]; Fiore, 2002). 
182 | Ritmos de cambio en la vestimenta y ornamentos de la sociedad Yagán...

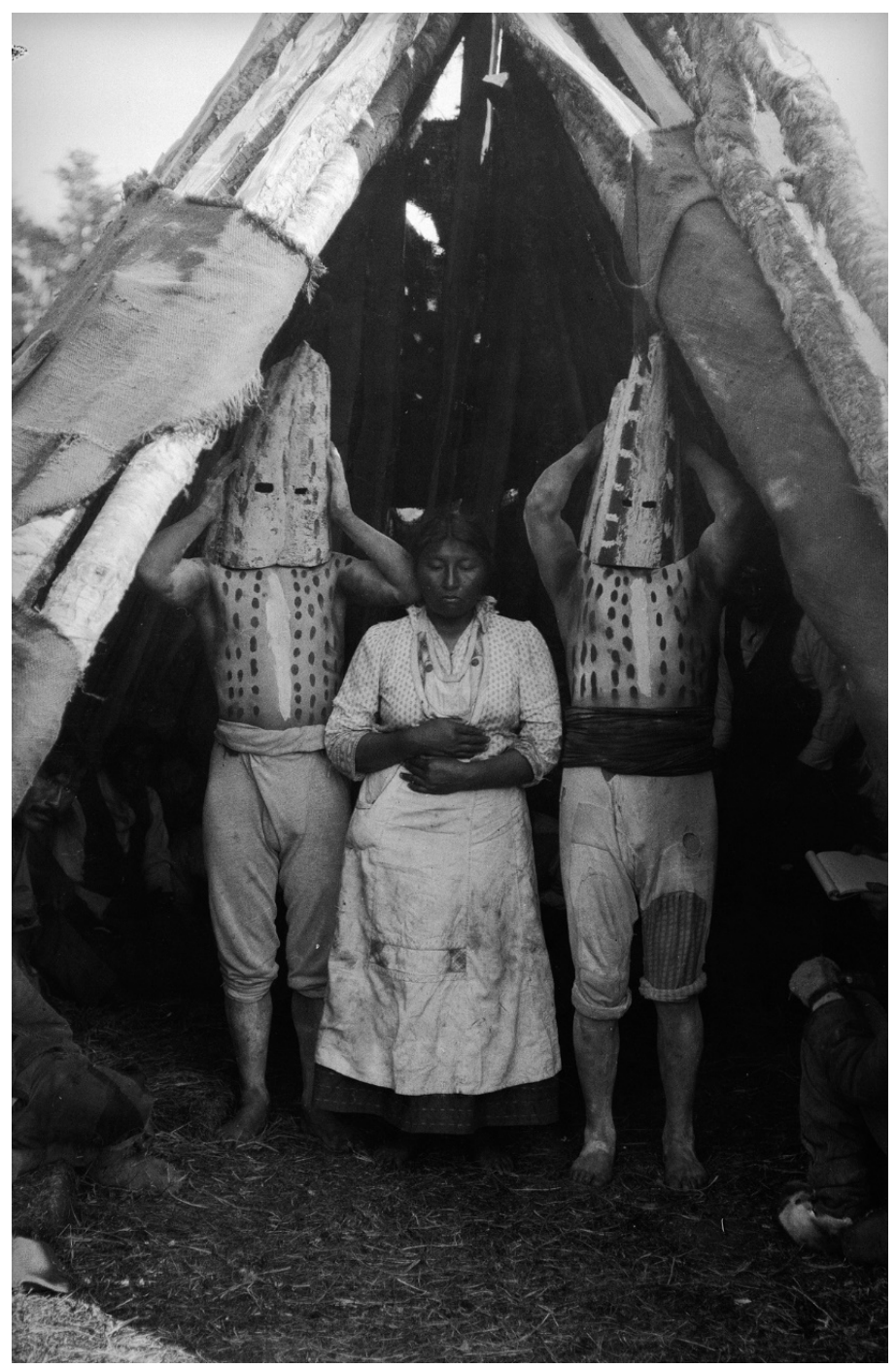

Imagen 5. Vista del interior de la choza del kina, donde los participantes visten pantalones arremangados y pintura corporal y máscaras ceremoniales tradicionales. Martin Gusinde, 1922.

Otra forma de adopción parcial de vestimenta occidental lo constituye la adopción y adaptación de las mantas de lana, convirtiéndose en un claro caso de ciclaje lateral que implica la transformación de las mantas de lana en capas a la usanza tradicional yagán. La adopción de estas mantas se caracteriza por: a) ser un material altamente disponible, b) no necesitar reciclaje ni otras manufacturas, c) no haber constituido un material económicamente caro, lo que facilitaba su donación o canje y d) ser un material lo suficientemente maleable, que permitía mantener una morfología similar a las capas de cuero autóctonas, y por lo tanto sostener la funcionalidad de la vestimenta yagán tradicional. 


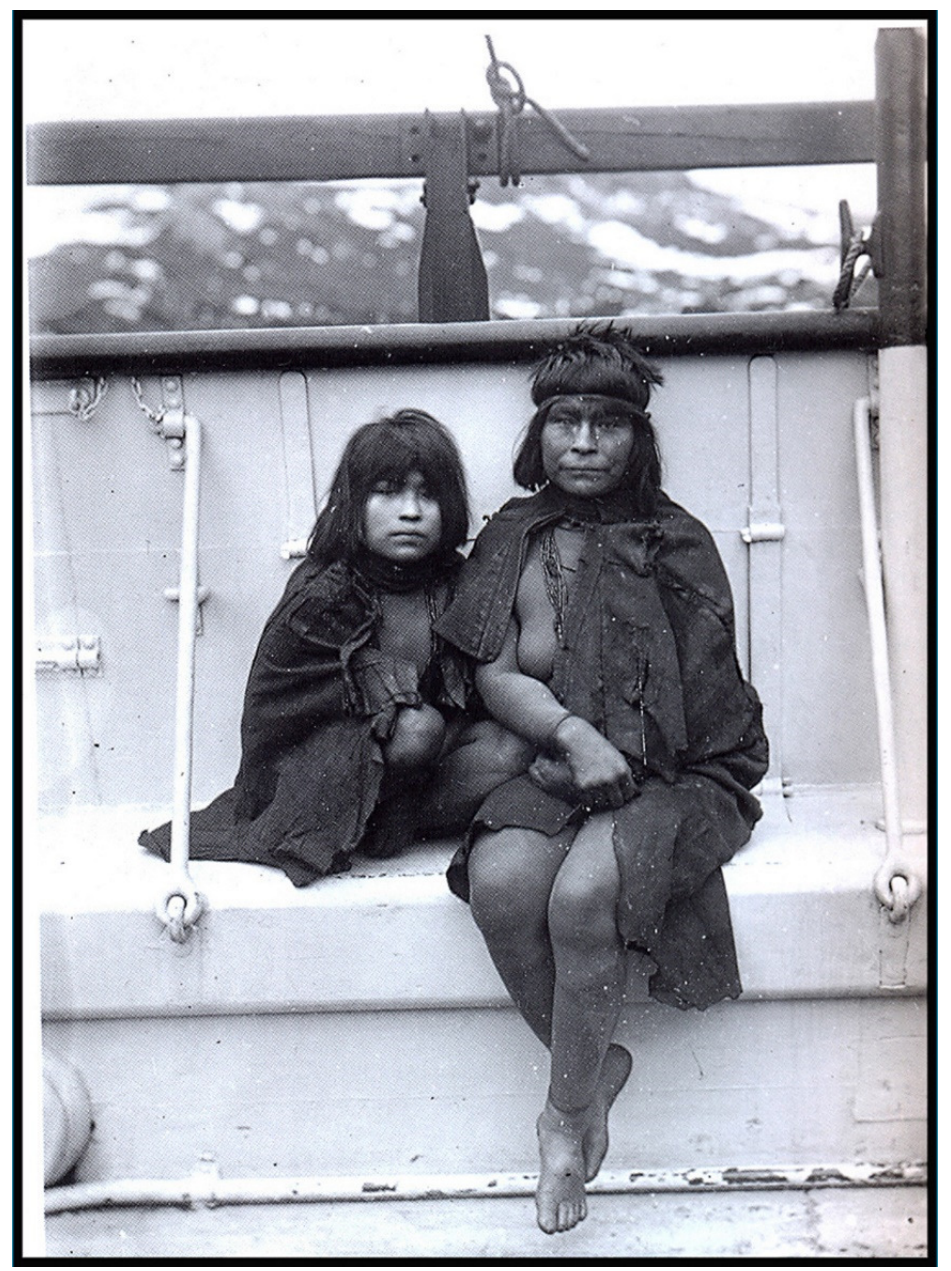

Imagen 6. Dos mujeres yagán visten mantas occidentales y adornos autóctonos a bordo de un barco. Jean Louis Doze y Edmond Joseph Payen, Misión Científica Francesa al Cabo de Hornos, 1882-1883.

No se han registrado casos de reciclaje de la vestimenta occidental, aunque sí existen casos de reciclaje de textiles occidentales para conformar parte de la cobertura de las chozas (Fiore y Butto, 2018). En este caso, observamos que el valor estuvo puesto en la materia prima, cambiando la funcionalidad del objeto de cultura material e incorporándolo en una esfera social distinta a la original (pasando de vestimenta a estructura habitacional).

En algunos de estos procesos es posible rastrear lo que entendemos como resiliencia, ya que permitió que el sistema cultural yagán mantuviera algunas prácticas tradicionales $\mathrm{y}$, por lo tanto, retornara a algún punto de equilibrio. Tal es el caso de la adopción parcial de la vestimenta occidental adaptada a las pinturas corporales ceremoniales y el mantenimiento de las diademas, las máscaras y la pintura corporal usadas en las distintas ceremonias de iniciación, incluso en momentos en los que ya se había adoptado ampliamente la ropa occidental (desde la década de 1910 en adelante). Consideramos que estos dos procesos indican un ritmo de cambio más lento en esos artefactos de 
184 I Ritmos de cambio en la vestimenta y ornamentos de la sociedad Yagán...

adorno debido a su valor social, que indica tanto roles dentro de la ceremonia (iniciando versus iniciado), como roles de género y edad dentro de la sociedad (Fiore, 2014). Así, estos objetos de adorno ceremonial condensan formas de reafirmación identitaria, de materialización de roles de poder y de resguardo de la memoria, esenciales para la reproducción del sistema social yagán. En esta situación colonial que alteraba el orden tradicional, esos adornos se convirtieron en núcleos estructurantes de la sociedad yagán y, por lo tanto, en los objetos de cultura material con el menor ritmo de cambio y la mayor capacidad para la resiliencia.

Por último, queremos subrayar que consideramos que en todos estos procesos está presente la agencia indígena: tanto en la negociación de qué objetos de cultura material occidental adoptar o no, como en la elección acerca de qué objetos de cultura material autóctona dejar de usar o mantener a lo largo del tiempo.

En síntesis, el caso yagán analizado en este trabajo ilustra claramente que los procesos de cambio generados mediante la interacción transcultural no son homogéneos, en tanto que, al ponerse en juego la agencia de las personas de ambos grupos interactuantes, los elementos de cultura material y las prácticas asociadas a ellos, se incorporan siempre de manera activamente negociada por los actores sociales involucrados. En tal sentido, la valoración utilitaria, social y económica que estos actores construyeron a partir de las distintas cualidades de los artefactos de cultura material en cuestión, influyó directamente sobre la continuidad de uso de determinados tipos de artefactos y sobre la incorporación de otros nuevos. Así, los actores sociales yagán fueron también agentes de su propio cambio cultural, que tuvo distintos ritmos según se tratara de una resiliencia protectora de prácticas tradicionales fundamentales para su reproducción social (que requirió un ritmo de cambio lento), o de una habituación a prácticas novedosas que les permitiera una viabilidad social en un contexto altamente occidentalizado (que requirió un ritmo de cambio más veloz). En ambos casos, los ritmos de cambio en la sociedad yagán estuvieron directamente asociados a su propia supervivencia física y cultural.

\section{Referencias bibliográficas}

Alvarado, M., Odone, C., Maturana F. y Fiore, D. (2007). Fueguinos. Fotografías siglos XIX y XX. Imágenes e imaginarios del fin del mundo. Santiago de Chile: Pehuén.

Barthes, R. (2004). La cámara lúcida. Buenos Aires: Paidós.

Bourdieu, P. (1979). La fotografía: un arte intermedio. México: Nueva Imagen.

Bridges, L. (2005 [1948]). El último confín de la tierra. Buenos Aires: Sudamericana.

Buscaglia, S. (2011). Contacto y colonialismo. Aportes para una discusión crítica en arqueología histórica. En S. Cornero e I. Dosztal (Comps.), Anuario de Arqueología, Actas del Primer Simposio de Arqueología Colonial, 3 (3) (pp. 57-76). Rosario: Universidad Nacional de Rosario. 
185 I Ana Butto y Danae Fiore

Butto, A. (2018). La representación del espacio misional y los indígenas evangelizados en las fotografías de las misiones anglicanas y salesianas de Tierra del Fuego (18691947). Cadernos de Arte e Antropologia, 7 (2), 97-115.

Butto, A. (2019). Huellas fotográficas de los pueblos originarios patagónico-fueguinos durante la conformación del Estado-nación argentino. En C. Hammerschmidt (Ed.), Patagonia literaria V. Representaciones de la identidad cultural mapuche (pp. 313-339). Potsdam: INOLAS Publishers.

Cardoso de Oliveira, R. (1963). Aculturación y “fricción” interétnica. América Latina 6 (3), 3-46.

Chaney, E. y Kathleen, D. (1989). “St. Augustine and the La Florida Colony: New Lifestyles in a New Land". En J. Milanich y S. Milbrath (Eds.), First Encounters: Spanish Explorations in the Caribbean and the United States, 1492-1570 (pp. 166-182). Gainesville: University of Florida Press.

Comaroff, J. L. (1992). Ethnography and the Historical Imagination. Boulder: Westview Press.

Cusick, J. (1998). Studies in Culture Contact: Interaction, Culture Change, and Archaeology. Carbondale: Southern Illinois University.

Darwin, C. (2000 [1839]). Diario del viaje de un naturalista alrededor del mundo (a bordo del navío HMS Beagle). Buenos Aires: El Aleph.

Dobres, M y Robb, J. E. (2000). Agency in Archaeology. Paradigm or platitude. London: Routledge.

Eicher, J. y Barnes, R. (1994). Dress and gender. Making and meaning in cultural contexts. Oxford: Berg.

Entwistle, J. (2000). The fashioned body. Fashion, dress and modern social theory. London: Polity Press.

Fiore, D. (2002). Body Painting in Tierra del Fuego. The power of images in the uttermost part of the world. Tesis doctoral. London: University of London.

Fiore, D. (2012). Diseños y tempos en el arte mobiliar del canal Beagle (Tierra del Fuego). Una exploración de los ritmos de cambio en la decoración de artefactos óseos. Relaciones de la Sociedad Argentina de Antropología, 37 (1), 183-206.

Fiore, D. (2014). Pinturas corporales fueguinas: una arqueología visual. En J. Oria y A. Tívoli (Eds.), Cazadores de mar y tierra. Estudios recientes en arqueología fueguina (pp. 409433). Ushuaia: Editora Cultural Tierra del Fuego.

Fiore, D. y Varela, M. L. (2009). Memorias de papel. Una arqueología visual de las fotografías de pueblos originarios fueguinos. Buenos Aires: Dunken.

Fiore, D. y Butto, A. (2018). Estructuras y paisajes en el fin del mundo. Implicancias arqueológicas y antropológicas sobre el emplazamiento de sitios mediante el análisis de fotografías de pueblos originarios fueguinos (circa 1880-1970). Relaciones de la Sociedad Argentina de Antropología, 43 (2), 231-260.

Fitz-Roy, R. (1839). Narrative of the surveying voyage of his majesty's ships. Adventure and Beagle between the years 1826 and 1836. London: Henry Colburn.

Foucault, M. (1988). Vigilar y castigar. Madrid: Siglo Veintiuno.

Freund, G. (2015 [1974]). La fotografía como documento social. Barcelona: Editorial Gustavo Gili.

García Canclini, N. (1989). Culturas hibridas: estrategias para entrar y salir de la modernidad. México: Grijalbo. 
186 | Ritmos de cambio en la vestimenta y ornamentos de la sociedad Yagán...

Gell, A. (1997). Art and agency. Oxford: Clarendon Press.

Giddens, A. (1995). La constitución de la sociedad: Bases para la teoría de la estructuración. Buenos Aires: Amorrortu.

Glantz, M. y Johnson, J. (1999). Resilience and Development: positive life adaptations. Nueva York: Plenum Publishers.

Gosden, C. (1999). Colonialism, ethnicity and post-colonialism. En C. Gosden (Ed.) Anthropology and Archaeology. A changing relationship (pp. 179-205.). London: Routledge.

Gramsci, A. (1980 [1949]). Notas sobre Maquiavelo, sobre la politica y sobre el Estado Moderno. Madrid: Ediciones Nueva Visión.

Gusinde, M. (1986 [1937]). Los indios de Tierra del Fuego. Los Yamanas. I-II-III. Buenos Aires: Consejo Nacional de Investigaciones Científicas.

Hyades, P. y Deniker, J. (2007 [1891]). Etnografía de los indios yaghan en la Misión científica del Cabo de Hornos 1882-1883. Punta Arenas: Ediciones Universidad de Magallanes.

Kossoy, B. (2001). Fotografía e historia. Buenos Aires: La Marca Editora.

Lehmann-Nitsche, R. (1915). Relevamiento antropológico de dos indias Alacaluf. Revista del Museo de la Plata, XXIII, 188-191.

Lothrop, S. (1928). The Indians of Tierra del Fuego. New York: Museum of American Indian.

McGuire, R. y Paynter, R. (1991). The Archaeology of Inequality. Oxford: Blackwell.

Orquera, L. A. y Piana, E. (2015). La vida social y material de los Yámana. Ushuaia: Monte Olivia.

Ortiz, F. (1983). Contrapunteo cubano del tabaco y el azúcar. La Habana: Editorial de Ciencias Sociales.

Piana, E. (2009). ¿Yámana o Yaghan? La mirada de Gusinde sobre los nómades del mar. En D. Fiore y M. L. Varela (Eds.), Memorias de papel. Una arqueología visual de las fotografías de pueblos originarios fueguinos (pp. 281-290). Buenos Aires: Editorial Dunken.

Redfield, R., Linton, R. y Herskovitz, M. (1936). Memorandum for the study of Acculturation. American Anthropologist, 38, 149-152.

Renfrew, C. y Bahn, P. (1998). Arqueología: teoría, métodos y prácticas. Madrid: Akal.

Scherer, J. C. (1992). The photographic document: photographs as primary data in anthropological enquiry. En E. Edwards (Ed.), Anthropology and Photography 18601920 (pp. 32-41). London: Yale University Press.

Shiffer, M. (1972). Archaeological Context and Systemic Context. American Antiquity, 37, 156-165.

Service, E. (1955). Indian-european relations in colonial Latin America. American Anthropologist, 57 (3), 411-425.

Silliman, S. (2001). Agency, practical politics and the Archaeology of cultural contact. Journal of Social Archaeology, 1 (2), 190-209.

Spicer, E. (1958). Social structure and the acculturation process. American Anthropologist, 60 (3): 433-441.

Spivak, G. C. (1994). Can the subaltern speak? En P. Williams y L. Chrisman (Eds.), Colonial and Postcolonial Theory (pp. 66-111). New York: Columbia University Press.

Trigger, B. (1996). History of Archaeological Thought. Cambridge: Cambridge University Press. 
187 I Ana Butto y Danae Fiore

Wallerstein, I. (1974). The Modern World System. Capitalist, Agriculture and the Origins of the European World Economy in the Sixteenth Century. New York: Academic Press.

Para citar este artículo:

Butto, Ana y Fiore, Danae (2020). Ritmos de cambio en la vestimenta y ornamentos de la sociedad Yagán de Tierra del Fuego (siglos XIX y XX). Anuario de la Escuela de Historia Virtual, 18, 158-187. 